\author{
Ольга Грейліх, \\ кандидат психологічних наук, \\ дочент кафедри психології \\ ДВНЗ «Переяслав-Хмельницький \\ державний педагогічний \\ універистет імені Григорія \\ Сковороди»
} E-mail: grejluh2008@ukr.net ORCID 0000-0003-4166-0542

\author{
Olga Greylih, \\ PhD (Psychology), \\ Associate Professor of Department \\ of Psychology \\ SHEI «Pereiaslav-Khmelnytskyi \\ Hryhorii Skovoroda \\ State Pedagogical University»
}

\title{
ТОЛЕРАНТНІСТЬ ЯК СКЛАДОВА КОМУНІКАТИВНОЇ КОМПЕТЕНТНОСТІ У ПЕДАГОГІЧНІЙ ДІЯЛЬНОСТІ
}

У статті розкрито сутність толерантності як базової складової комунікативної компетениії особистості. Проаналізовано теоретичні підходи до визначення поняття толерантність та комунікативна компетентність у діяльності педагога. Акцентовано важливість комунікативної компетентності для успішності реалізації професійного потенціалу вчителя. Обгрунтовано механізми комунікативної компетентності, де толерантність є одним 3 ї̈ механізмів. Зазначено специфіку комунікативної компетентності педагога, яка проявляється в тому, щзо вона має бути атрибутом як самого вчителя, так і метою його діяльності. Показано, щчо педагог повинен логічно мислити, чітко формулювати свою думку, аргументувати ї̈, при иььму дотримуватися формальних та неформальних правил етики ділового спілкування, уміти читати невербальні знаки комунікації, налагоджувати зв'язок, проявляти емпатію та формувати компетентність в учнів. 3'ясовано, щчо ефективність навчання та формування комунікативної компетентності $і$ толерантності як ї̈ складової залежить від відповідних методик $і$ технік, які сприяють не лите засвоєнню нових знань, а й мотивують до самоосвіти $i$ саморозвитку. Визначено значущістьь формування комунікативної компетентності в ранньому віці. Запропоновано кейси "Один в групі», "Чужинець», "Я інший», "Я такий», «Чого не вистачає?», які сприяють формуванню толерантного ставлення учнів до представників різних соиіальних груп, орієнтують дітей на вихід з власної зони комфорту та «примірювання» на себе інших сочіальних статусів і ролей. Проаналізовано підходи до вивчення поняття комунікативної компетентності $i$ толерантності майбутнього фахівия педагогічної сфери. Означено толерантність як сукупність комунікативних, перцептивних та інтерактивних знань $і$ вмінь, які визначають спроможність суб 'єкта орієнтуватися в міжособистісній взаємодії. Доведено, що сучасна освіта вимагає від педагога нових підходів до розуміння освітнього прочесу через формування компетенцій.

Ключові слова: комунікація, спілкування, педагогічна толерантність, формування толерантності, терпимість, компетентність.

The article reveals the essence of tolerance as the basic component of the communicative competence of the individual. The theoretical approaches to the definition of the concept of tolerance and communicative competence in the activity of the teacher are analyzed. It is revealed that in pedagogical activity communicative competence is important for the success of realization of professional potential of the teacher. The article substantiates the mechanisms of communicative competence, where tolerance is one of its mechanisms. Specifies the communicative competence of the teacher, which is manifested in the fact that it should be an attribute of the teacher himself and the purpose of his activity. It is shown that the teacher should think logically, clearly formulate his opinion, argue it, while adhering to formal and informal rules of ethics of business communication, be able to read nonverbal signs of communication, to establish communication, to exhibit empathy; and to develop competence in students. It has been determined that the effectiveness of learning and the formation of 


\section{Psychology}

communicative competence and tolerance as a component of it depends on appropriate techniques and techniques that contribute not only to the acquisition of new knowledge, but also to motivate selfeducation and self-development. The aspects of formation of communicative competence at an early age are determined. The article proposes cases such as "One in the group», «Stranger», «I am different», «I am», "What is missing?», Which promote the formation of a tolerant attitude of students to representatives of various social groups, orienting children to the exit from their own comfort zone and "tune in" to other social statuses and roles. The article emphasizes the importance of tolerance and its components, which ensure the success of the teacher. The approaches to the study of the notion of communicative competence and tolerance of the future specialist of the pedagogical sphere are analyzed. The prospects of the development of tolerance of a specialist in the pedagogical sphere are outlined. Tolerance is indicated as a set of communicative, perceptual and interactive knowledge and skills that determine the ability of the subject to navigate in interpersonal interaction. It is proved that modern education requires from the teacher new approaches to understanding the educational process through the formation of competencies. competence.

Keywords: communication, pedagogical tolerance, tolerance formation, tolerance,

Постановка проблеми. Сучасна світова наукова спільнота звертає увагу на толерантність як необхідну умову педагогічного спілкування та компетентність, яку потрібно сформувати в учнів для успішного розвитку в сучасному мінливому глобалізаційному світі. У навчальних закладах дитина вперше набуває практики спілкування з людьми, інакшими за різними соціальними та індивідуальними ознаками. Тому в цей період формується ставлення до оточуючих та оцінні моральні й естетичні характеристики дійсності. Ось чому толерантність $є$ тією необхідною складовою комунікативного простору, без якої неможливо уявити будьяку педагогічну спільноту та соціум.

Аналіз останніх досліджень $\boldsymbol{i}$ публікацій. Толерантність, як складова комунікативної компетентності педагогічної діяльності, потребує сучасних наукових інтерпретацій у контексті психологічного знання. Метою $\epsilon$ дослідження толерантності у контексті комунікативної компетентності, а методологічну основу становлять методи аналізу та синтезу, що дозволяють виявити сутність толерантності як складової комунікативної компетентності.

Толерантність $є$ важливою комунікативною компетентністю сучасного педагога та компетентністю, яку він повинен сформувати у вихованців і школярів шляхом навчання та виховання як фундаментальної передумови мирного співіснування у полікультурному соціальному просторі. Толерантність $є$ моральним викликом сучасності не лише в контексті професійного спілкування, а й звичайної буденної практики. Визнання цінності особистості іншого незалежно від політичних, релігійних, національних поглядів i переконань сприяє мирному співіснуванню культур, народів, етносів.

Аналіз сучасних наукових вітчизняних та зарубіжних розвідок свідчить про зростання інтересу до даної теми та про ії актуальність упродовж історії. Представники наукової когорти Нового часу та просвітники Дж. Локк， Ф. Вольтер， Д. Дідро， Ж.-Ж. Руссо， а пізніше 
Ю. Габермас, М. Уолцер наголошували на важливості принципу толерантності в контексті соціальних взаємодій. У 1948 році перед світовою спільнотою постала необхідність прийняття «Загальної декларації прав людини», в якій зазначається, що «усі люди народжуються вільними і рівними у своїй гідності та правах. Вони наділені розумом і совістю й повинні діяти по відношенню один до одного в дусі братерства» [Всеобщая декларащия ..., 1948]. Сучасні вітчизняні науковці С. Бричок, А. Горянська, Г. Денисенко, І. Кривошапка, С. Матвієнко, М. Окса досліджують толерантність у контексті педагогічного спілкування в сучасному суспільстві. А О. Савченко вважає, що толерантність необхідно віднести до ключових компетентностей, які слід формувати у школі спеціальними технологіями через «культурно збагачене навчальне та виховне середовище, яке повинно мати ознаки: відкритість, демократичність, емоційна комфортність, суб'єктність навчальної взаємодії» та наголошує на важливості активної толерантної позиції вчителя [Савченко, 2017: c. 14].

У дослідженні Г.Кінга, присвяченому ролі демократичних цінностей у початковій школі, аналізуються різні світові шкільні моделі та зазначається, що, до прикладу, австралійська модель розрахована на очікування батьків у формуванні в школі таких цінностей: толерантність, довіра, чесність, співчуття та ввічливість [King,2005: c. 52]. М. Кошева і М. Гайдіняк досліджують толерантність у контексті болгарської освіти та вважають, що інтегрована школа (інтернаціональна) може «розглядатися як універсальна медицина» для інтеграції соціуму та успішних соціальних взаємодій [Kosseva, Hajdinjak, 2011: c. 12]. Цікавим є дослідження толерантності i культурного різноманіття в школах М. Массена та В. Бадера 3 Амстердамського університету. Тут знаходимо типи культурного різноманіття в шкільному житті, виявлення толерантних i нетолерантних практик в освітній діяльності, а також розглядаються мультикультуралізм, лібералізм, повага, розуміння, національні традиції у контексті толерантності [Maussen, Bader, 2012].

Метою cmammi $\epsilon$ аналіз особливостей толерантності та ii механізми, які є важливим аспектом спілкування сучасного педагога.

Виклад основного матеріалу. Толерантність $є$ тією необхідною складовою комунікативного простору, без якої неможливо уявити будь-яку педагогічну спільноту, та показником високого рівня культури вчителя. Сучасна освітня вітчизняна парадигма зорієнтовує освітній процес не на навчання як засвоєння необхідних знань 3 певних предметів, передбачених шкільною програмою, а на набуття компетенцій для успішного подальшого життя. Головний критерій освітнього процесу - це не знати, а уміти реалізовувати знання в практичній площині, бути підготовленим до життя, вміти відстоювати свої інтереси, презентувати та втілювати власні ідеї, тобто вміти бути відповідним викликам і потребам сучасності й реалізувати себе. Це можливо за умови наявності відповідних компетентностей, однією з найважливіших серед яких є комунікативна. 


\section{Psychology}

Комунікативна компетентність передбачає сукупність різновекторних знань, умінь та навичок. Зокрема це i знання мовних конструкцій, і фонетичні уміння, і здатність до емпатії, і володіння техніками ораторського мистецтва та психологічними методиками самоконтролю й контролю ситуації, і моральні виміри, такі як повага, толерантність, співчуття й милосердя.

У педагогічній діяльності комунікативна компетентність є необхідною для успішності як реалізації професійного потенціалу вчителя, так і результативності освітнього процесу. Специфіка комунікативної компетентності педагога проявляється в тому, що вона має бути атрибутом як самого вчителя, так і метою його діяльності. Педагог сам повинен логічно мислити, чітко формулювати свою думку, аргументувати іiі, при цьому дотримуватися формальних та неформальних правил етики ділового спілкування, уміти читати невербальні знаки комунікації, тримати аудиторію й проявляти емпатію; і при цьому ще й сформувати їі в учнів. Якщо більшість видів діяльності передбачають цю компетентність як інструмент успішної реалізації себе в професії, використовуючи різні техніки маніпулятивного впливу для досягнення мети, то педагог повинен керуватися критеріями істинності та моральності. Тому толерантність $є$ однією з найважливіших складових компетентності у даному випадку.

Проблема толерантності існує в усіх сферах життєдіяльності людини i не має етнічних, культурних чи політичних обмежень. У декларації принципів толерантності зазначено, що вона передбачає повагу, прийняття та правильне розуміння багатого різноманіття культур, форм самовираження та самовиявлення людської індивідуальності, політичну й правову потребу, активну позицію, що формується на основі визнання універсальних прав та основних свобод людини. Проте, саме в освітній сфері, починаючи 3 дошкільних закладів, дитина вперше повною мірою входить у різнорідне соціальне середовище і починає шукати й виборювати своє місце серед різних інакших. Для дитини це великий проміжок часу у декілька годин на добу кілька днів підряд, коли вона перебуває віддалено від групи (сім’ї), до якої належить і де все зрозуміло. У малій групі існує тісний взаємозв'язок між іiі членами, реакція на дії чи слова один одного передбачувана у більшості випадків, або очікувана, а спорідненість смаків, інтересів, цінностей очевидна. У садочку чи школі їй доводиться взаємодіяти 3 іншими людьми у різнорідному середовищі. Вони різняться за ознаками зовнішніми і внутрішніми, об'єктивними i суб'єктивними. Це середовище може бути полікультурне, поліетнічне, поліконфесійне тощо і характеризується своїми власними цінностями та смисложиттєвими орієнтаціями. Відповідно повинен спрацьовувати якийсь внутрішній захисний механізм, що завадить конфліктності ситуацій у ході інтеракцій та допоможе уникнути формування образу ворожості у сприйнятті інакшості. Ним виступає природна здатність людини до спілкування. Однак успішність цього спілкування буде залежати від 
наповнення цієї здатності знаннями, уміннями, навичками у результаті буденних комунікативних практик. Тому на педагога різних рівнів освітнього процесу покладена місія правильного наповнення при формуванні комунікативної компетентності дитини. Це можливо за умови сформованості її у самого вчителя і його професійної майстерності.

Від представників педагогічної професії соціум очікує не лише високої освіченості й майстерності, а й поведінкової зразковості поза навчальним процесом. За будь-яких обставин, незалежних від професії, національності, політичної чи релігійної приналежності тощо, спілкування повинно бути спрямоване на створення оптимальних умов для досягнення взаєморозуміння й взаємодії між учасниками соціальних інтеракцій, а толерантність - невід'ємною його складовою.

Учитель повинен чітко усвідомлювати й засобами педагогічних методик i технік формувати в дітей толерантність у контексті комунікативної компетентності, що проявляється у наступному:

- розуміння того, що світ складний i різноманітний, а життя кожного є цінністю. Усі люди різняться за зовнішніми ознаками і мають свій внутрішній глибокий світ. Окрім того, вони об'єднані за родовою, етнічною, релігійною ознакою. I всі без виключення варті життя та перебувають у пошуку свого комфортного місця. Тому ми повинні усвідомити цінність самого життя;

- навчитися сприймати різноманітність у поглядах, переконаннях, приналежностях, зовнішніх проявах як природне. «Різниця у поглядах, мові або переконаннях не заважає нам знайти спільну мову і можливість мати схожі погляди і цілі на майбутнє. С лише єдине виключення свобода самовираження може бути обмежена лише тоді, коли це загрожує самовираженню іншої особи» [Ярошенко,2017: с. 76];

- критично ставитися до себе та оточуючих: не сприймати все на віру, а піддавати логічній аргументації. Розуміти, що в кожного є підстави мати той чи інший погляд на одну й ту ж річ чи подію і кожен може помилятися. Це залежить від багатьох факторів: рівня обізнаності, причетності, релігійних переконань, психологічних характеристик тощо;

- важливо пізнавати різні культури, релігії, вміти аналізувати політичні погляди за допомогою пізнавальних засобів: читання, відвідування культурно-просвітніх заходів тощо;

- лотримуватися завжди правил культури спілкування.

Формування толерантного ставлення до дійсності важливе для адекватного розуміння навколишнього світу та сприйняття інших, відмінних, зосередження на бажаному i можливому майбутньому, знаходження спільних інтересів та об'єднання їх навколо однієї проблеми, зосередження на спільній діяльності.

Толерантність у контексті педагогічної комунікації розуміється як повага і визнання рівності різноманітності учнів, відмова від домінування i насильства старших над меншими (педагогів над учнями), визнання 


\section{Psychology}

різноманіття культурних норм, відмова від зведення цього різноманіття до спільного (одного) знаменника чи переваги якої-небудь однієї точки зору. Толерантність означає визнання прав дітей, сприйняття їх як собі рівних, високий рівень емпатії, готовність прийняти приналежність їх до різних культур та релігій такими, якими вони є, та взаємодіяти 3 ними на основі рівності та поваги. Ключова теза толерантності - це цінність життя людини, і будь-хто інший не має права на приниження гідності та невизнання права на її повноцінне існування у світі.

Толерантність вимагає від людей дотримання поваги прав і свобод людини, визнання права на власну думку й права мати іï іншим, робити вибір і визнавати право вибирати за іншими, бути приналежним до різних релігійних політичних груп і усвідомлювати приналежність до інших груп, часто протилежних за ідейним наповненням. Тому для людини важливо ще 3 раннього віку усвідомити принцип толерантності співіснування у соціумі, порушення яких сприяє проявам агресії, неадекватності, що призводить до конфліктних ситуацій. Завдяки організації та проведенню педагогами формальних та неформальних заходів, в закладах освіти можливо сформувати та зміцнити у молодого покоління толерантне ставлення до інших, через прийняття та усвідомлення відмінностей як очевидного, природного.

Пропонуємо декілька кейсів, які можна використати під час проведення тренінгів 3 метою формування толерантності у контексті комунікативної компетентності. Вони можуть використовуватися під час проведення різних видів занять і можуть бути видозмінені. Проте більшість подібних кейсів орієнтуються на вихід з власної зони комфорту та «примірювання» на себе інших соціальних статусів i ролей, тобто спробувати побути іншим у різних ситуаціях.

Кейс 1. «Один у групі». Цей кейс дозволить «побути» в психологічному стані людини, яка не є частиною групи, вона одна. Для цього нам потрібно виготовити декілька різних емблем однакової кількості та одну в єдиному варіанті з захисним верхнім шаром. Зовні вони всі однакові. Роздаємо їх кожному в групі, але слідкуємо, щоб емблема, яка є в єдиному екземплярі, не потрапила аутсайдеру, якщо такий є в групі. На рахунок «три» пропонуємо зняти захисний шар і знайти своїх. У результаті маємо кілька рівних за кількістю груп і одного розгубленого учасника, що перебуває в безрезультатному пошуку. Ведучий пропонує йому дати відповіді на наступні запитання:

- Що ти відчув, коли зрозумів, що ти такий один?

- Чи потрапляв ти в подібну ситуацію в житті? Які відчуття переживав і чи схожі вони з сьогоднішніми?

Потім пропонується долучитися до обговорення всім присутнім та розповісти про їхні відчуття, коли знаходили своїх, і за яким принципом i чи хотіли би бути на місці самотнього учасника. Кожна людина може пригадати кілька подібних випадків зі свого життя. Тому слід наголосити 
на важливості толерантного ставлення до інших, оскільки життя непередбачуване і життєві ситуації можуть бути різними.

Кейс 2. «Чужинець». Цей кейс проводиться у формі гри. Вибираємо одного учасника шляхом жеребкування. Він один, а всі решта стають у тісне коло і їхнє завдання - не впустити чужинця. «Чужинець» повинен використати всі можливі варіанти, допускаючи маніпуляції, пробратися в коло, стати одним з групи. Коли учасник потрапляє до кола, обирається інший «чужинець». А потім проводиться інтерактив для виявлення відчуття людини, яка пробує бути частиною групи, та обговорення способів приєднання.

Кейс 3. «Я інший». Цей кейс, як і інші, використовується для тимчасової підміни психологічного стану особистості, з метою розуміння людей приналежних до різних національностей чи релігійних конфесій. Ведучому варто бути дуже обережним і слідкувати, щоб учасник «набув» не свого статусу.

Учасникам по одному пропонується витягти 3 коробки якийсь предмет 3 національною символікою, інші виступають у ролях байдужих або непримиренних до представників інших народів. Таким чином, штучно створюється конфліктна ситуація та обов'язково обмежується часом близько двох хвилин. Кожен 3 учасників під час тренінгу повинен бути в тій і іншій ролі.

Цей кейс варіативний. Замість національної ознаки може використовуватися будь-яка інша, залежно від загальної ситуації в колективі. Це може бути й релігійна ознака, а також використовуватися атрибути наявних у суспільстві субкультур, або силові, якщо у шкільному середовищі є таке явище, як булінг тощо.

Кейс 4. «Я такий». Цей кейс $є$ популярним у психологічній практиці, може охоплювати як малу групу, так і проводитися у вигляді масштабної акції. У першому випадку пропонується учасникові описати себе, як він бачить свій образ, на невеликому папері, або вирізати себе i прикріпити на великому аркуші паперу, що символізує даний колектив. У результаті ми бачимо сукупність різних образів, що складаються в цілісність однієї групи.

Таким чином кожен має усвідомити, що він $є$ повноцінним членом групи зі своєю данністю, можливостями і бажаннями, і це є цінним, проте кожен інший цінний також. Тому потрібно знайти механізми ефективного існування всіх в одному цілому. Одним 3 них є толерантність. Вона містить у собі певне ставлення до інших поглядів або вчинків, кожна людина має право на власні погляди, відмінні від інших, переконання у своїй правоті, але не має права на шовінізм. Дитина повинна чітко усвідомити, що вона має права і свободи такі ж, як інші. «Виховання в дусі толерантності має бути направлене на протидію впливу, що викликає почуття страху i відчуження відносно інших. Воно повинно сприяти формуванню у молоді навичок незалежного мислення, критичного осмислення і виробленню 


\section{Psychology}

суджень, заснованих на моральних цінностях» [Декларащия принцииов..., 1995].

Кейс 5. «Чого не вистачає?» Цей кейс передбачає виявлення колективного уявлення про толерантність та індивідуальної самокритичності. Спершу пропонується разом визначити сутнісне значення поняття толерантності. Для цього малюється велике коло, що символізує толерантність, потім розбиваємо його на стільки сегментів, скільки ознак толерантності виявлено методом «мозкового штурму», i записуємо їх. Робимо кілька наліпок на кожному сегменті $з$ відповідним написом: терпимість, чуйність, уважність, довіра, співчуття, доброзичливість, почуття гумору, здатність допомогти незнайомому тощо. Потім пропонується кожному учаснику взяти ту наліпку (може й декілька), яка символізує якість, якої, на його думку, не вистачає у нього й обов’язково обгрунтувати свій вибір.

Результативність проведення подібних кейсів вбачається як у виявленні проблеми, так і в пошуку шляхів їх вирішення через формування толерантного ставлення до інших, відмінних за кольором шкіри, фізіологічними чи психологічними характеристиками, статевою ознакою, типами поведінки, національністю, смаками тощо. Подібні кейси дозволяють не просто роз'ясняти, що інакшість - це норма, що всі люди різні і кожен прийшов у цей світ жити, та є цінністю сам собою, а й «приміряти на себе» інші соціальні статуси та відповідні їм ролі й відчути їх емоції, перебуваючи тимчасово в іншому психологічному стані.

Тренінги, спрямовані на формування комунікативної компетентності у контексті толерантності, варто періодично проводити у рамках різних заходів як в учнівському колективі, так і в педагогічному. Важливі якості для можливості постійного розвитку людини та їі успішної реалізації у соціумі необхідно час від часу «прокачувати», говорячи мовою сучасного коучингу. Оскільки від сучасного вчителя вимагається бути толерантним і вчити бути толерантними учнів. Уміти самому і вчити інших досягати взаєморозуміння та узгодження різноманітних поглядів на одні й ті ж проблеми у процесі спілкування. Уміти подивитися зі сторони на протилежну точку зору, сприйняти її як таку, що має право на існування. Намагатися без застосування авторитарних методів досягати компромісних рішень та об'єднувати різні точки зору на одну і ту ж проблему. У процесі педагогічного спілкування толерантність передбачає визнання права на інакодумство. Толерантність для вчителя - це бачити дітей такими, якими вони є.

Роль учителя у формуванні особистості є вагомою, можна сказати пріоритетною. Особистість якраз і передбачає набуття соціальних ознак, норм та правил для ефективного існування у соціальному різноплановому середовищі. Ефективність багато в чому залежить від комунікативної

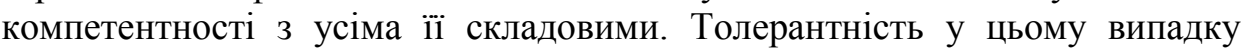
виступає однією 3 ключових складових. Сучасна освіта вимагає від 
педагога нових підходів до розуміння освітнього процесу через формування компетенцій. Практика показала, що володіння сукупністю знань без уміння їх реалізації спричиняє низьку результативність у професійній сфері. Сучасна людина повинна уміти застосувати той максимум і мінімум своїх умінь та можливостей для самореалізації. Це можливо завдяки формуванню з раннього віку компетентностей, серед яких комунікативна $\epsilon$ ключовою. А толерантність як складова комунікативної компетентності необхідна для успішного розвитку особистості й реалізації у полікультурному та полірелігійному суспільстві.

Толерантність виступає механізмом урегулювання взаємодій, а тому іiі слід формувати в контексті комунікативної компетентності, починаючи 3 раннього періоду соціальних взаємодій. Ці взаємодії починаються в сім’і, проте тут існують спільні правила, норми та цінності. A, починаючи 3 дошкільних закладів, людина повинна усвідомлювати нормальність відмінності та цінність кожного, вміти знаходити компроміси у різнорідному соціальному середовищі. Педагог найбільше з усіх агентів соціалізації доносить інформації про світ, про його різноманітність і саме на нього покладена соціальна відповідальність за інтелектуальний та емоційний розвиток наступних поколінь, від яких залежить і розвиток соціуму загалом.

Ефективність навчання та формування комунікативної компетентності і толерантності, як іiі складової, залежить від підбору вчителем відповідних методик і технік, які сприяють не лише засвоєнню нових знань, а й мотивують до самоосвіти і саморозвитку.

Висновки. Проблема толерантності ставить нові завдання в системі сучасної не лише вітчизняної, а й світової освіти. Сучасне суспільство потребує освіти, зорієнтованої на оволодівання компетенціями професійного спрямування, що включають і комунікативну, як необхідну для успішності реалізації індивіда в швидкозмінному, інформаційно насиченому соціальному бутті. Комунікативну компетентність важливо формувати з раннього віку. Вона включає прийняття, визнання та цінність кожної людини - толерантність.

Толерантність передбачає визнання права іншого на рівноцінне існування та $\epsilon$ запорукою розвинутого демократичного суспільства. Тому важливою компетентністю сучасного педагога $є$ толерантність як повага та визнання різноманітності. Окрім того, це не лише вимога до особистісної професійної компетенції сучасного вчителя, а й мета освітнього процесу, що спрямовує діяльність у напрямку формування толерантності як складової комунікативної компетентності учнів. Для цього в нашому дослідженні запропоновано кейси, які сприяють формуванню толерантного ставлення учнів до представників різних соціальних груп. Наступним кроком наукових розвідок у цьому контексті стануть пошуки нових практик, спрямованих на ефективність формування толерантності у молоді. 


\section{Psychology}

\section{ЛITЕРАТУРА}

Всеобщая декларащия..., 1948 - Всеобщая декларация прав человека. Принята и провозглашена в резолюции 217 А (III) Генеральной Ассамблеи от 10 декабря 1948 года - [електронний pecypc] - (режим доступу) http://zakon.rada.gov.ua/laws/show/995_015.

Декларация принципов..., 1995 - Декларация принципов терпимости утверждена резолюцией 5.61 Генеральной конференции ЮНЕСКО 16 ноября 1995 года - [електронний ресурс] (Режим доступу) http://zakon.rada.gov.ua/laws/show/995_503?lang=uk.

Савченко, 2017 - Савченко О. Толерантність як цінність шкільної освіти. Інноваційна педагогіка. 2017. Вип. 1. С. 13-16. (Режим доступу) http://nbuv.gov.ua/UJRN/innped_2017_1_4.

Ярошенко, 2017 - Ярошенко Є. Філіпчук В., Мішель де Клерк. Толерантність та як про неї говорити: посібник з миробудівництва в Україні. - [електронний ресурс] - режим доступу: http://www.icps.com.ua.

King, 2005 - Gregory King. The Role of The Principal in Fostering the Practice of Democratic Values in a Primary School South Africa, University of the Western Cape (2005) (Режим доступу) [електронний ресурс] - http://hdl.handle.net/11394/1482.

Kosseva, Hajdinjak, 2011 - Maya Kosseva, Marko Hajdinjak (2011)Tolerance Of Difference In Bulgarian Schools: Discourses And Practices European University Institute, Florence Robert Schuman Centre for Advanced Studies- Published by the European University Institute [електронний ресурс] - (Режим доступу) URI: http://hdl.handle.net/1814/19791.

Maussen, 2012 - Marcel Maussen, Veit Bader, Tore Vincents Olsen, Jon Fox, Zsuzsanna Vidra, Jan Dobbernack and Tariq Modood (2012). Tolerance and cultural diversity in schools Comparative report, University of Amsterdam, Published by the European University Institute - [електронний ресурс ] https://pure.uva.nl/ws/files/2112300/148643_ACCEPT_2012_01_WP3_ComparativeReport_ Ch1.pdf.

\section{REFERENCES}

Vseobshchaia deklaratsyia..., 1948 - Vseobshchaia deklaratsyia prav cheloveka Pryniata y provozghlashena v rezoliutsyy 217 A (III) Heneralnoi Assambley ot 10 dekabria 1948 hoda [elektronnyi resurs] - (rezhym dostupu) http://zakon.rada.gov.ua/laws/show/995_015.

Deklaratsyia pryntsypov..., 1995 - Deklaratsyia pryntsypov terpymosty utverzhdena rezoliutsyei 5.61 Heneralnoi konferentsyy YuNESKO 16 noiabria 1995 hoda - [elektronnyi resurs] - (Rezhym dostupu) http://zakon.rada.gov.ua/laws/show/995_503?lang=uk.

Savchenko O., 2017 - Savchenko O. Tolerantnist yak tsinnist shkilnoi osvity / O. Savchenko // Innovatsiina pedahohika. - 2017. - Vyp. 1. - S. 13-16. (Rezhym dostupu) http://nbuv.gov.ua/UJRN/innped_2017_1_4.

Iaroshenko Ye., 2017 - Yaroshenko Ye. ta in. Tolerantnist ta yak pro nei hovoryty: posibnyk z myrobudivnytstva v Ukraini / Yevhen Yaroshenko, Vasyl Filipchuk, Mishel de Klerk [elektronnyi resurs] - rezhym dostupu: http://www.icps.com.ua. 